\title{
The Social Value Act 2012: Current state of practice in the social housing sector
}

\author{
Alex Opoku ${ }^{1}$ and Peter Guthrie ${ }^{2}$ \\ ${ }^{1}$ UCL Bartlett School of Construction \& Project Management, University College London \\ ${ }^{2}$ Centre for Sustainable Development, Department of Engineering, University of Cambridge
}

\begin{abstract}
Purpose - The social housing sector is under increasing pressure to do more with less and provide value for money as part of the UK Government's public debt reduction strategy. This study explores the current practices towards unlocking social value in housing sector through the adoption of the Social Value Act 2012. The Social Value Act seeks to ensure that public sector procurement deliver added value in terms of social, economic and environmental outcomes.
\end{abstract}

Research Approach - The study adopts quantitative research methodology through a survey with 100 housing professionals charged with the delivery of social value outcomes in the social housing sector in England.

Findings - The results of the study reveal that, there is a low level of understanding of the Social Value Act 2012 among professionals in the social housing sector. Once again, most organisations in the social housing sector do not have social value strategies or policies and rarely consider social value outcomes during procurement. However, employment skills and training, and crime and anti-social behaviour reduction are the most social value priority outcomes/needs identified with organisations currently promoting social value in the social housing sector.

Social Implications - The issue of social value has a huge importance to the wider society and the study provides an insight into current practices towards the realisation of social value outcomes in the housing sector.

Originality - The Social Value Act 2012 came into force in January 2013 and little has been written on the impact of the Act on the social housing sector in England. This study identifies current practices in the social housing sector towards the delivery of social value outcomes in the day-to-day business operations.

Keywords: England, Social Value, Social Value Act 2012, UK, Social housing, Value for money 


\section{Introduction}

The UK Government is currently cutting down public subsidy to the social housing sector and also demanding the true value of their programmes in order to justify continued funding support from the public purse. Value has been defined to include economic, socio-cultural, political and environmental benefits beyond the delivery of the core services (National Health Service-NHS, 2015). Value for money (VfM) is an issue of growing concern across the housing sector and this requires a better understanding of performance improvement of the housing assets (Jones and Wilson, 2014). Sustainable procurement processes are important in promoting good performance and value for money culture in the housing sector when delivering housing products. The housing sector is required to deliver substantial value beyond the development of new housing products (Johnson and Sommariva, 2012). However, prior to the introduction of the Social Value Act 2012, the social housing sector has long been committed to investment programmes that contribute to positive social impact on the communities they operate; there is a growing recognition that housing providers should ensure significant contribution to social value creation when measuring value for money (Trotter et al., 2014).

It is believed that organisations that position social value at the heart of its operations are competitive and successful in the society (Harlock, 2014). Through the creation of social value, the housing sector and affordable housing providers have the opportunity to make additional positive impact on the communities they operate, through improved maintenance work, working with local contractors, businesses, schools and the adoption of sustainable procurement options (National Federation of Arm's Length Management OrganisationsALMOs, 2013). Social value principles mean scarce resources are well allocated and the valuation of contracts should go beyond the price, to seek the wider benefits to the community (Duncan and Thomas, 2012). This paper aims at exploring the current state of practice towards the creation of social value in the social housing sector following the introduction of the Social Value Act 2012. The paper begins with a review of relevant literature on social value, the Social Value Act 2012 and the possible implications on the housing sector. The second section presents the adopted research approach and the research findings. The final part of the paper is devoted to the research conclusions and the implications of the study on the housing sector. 


\section{Unlocking Social Value}

There is no single definition of social value and Temple et al. (2014) argue that, defining social value is as difficult as delivering and measuring it. However, social value is believed to involve the recognition of the importance of social, environmental and economic impacts on the community and the people living in these communities. Common among the many definitions of social value is that of the Sustainable Procurement Task Force, which defines social value as "a process whereby organisations meet their need for goods, services, works and utilities in a way that achieves value for money on a whole life basis, in terms of generating benefits to the society and the economy, whilst minimising damage to the environment” (Department for Environment, Food and Rural Affairs-DEFRA, 2006:10). Harlock (2014) however defines social value as the additional environmental, social and economic benefits to the communities of operation above and beyond the delivery of the primary service. Creating social value should improve the lives of people in our communities; provide career and skills development opportunities as well as making positive contribution to the environment. The term social value has been used to describe the additional value created such as employment opportunities in the delivery of the primary service or Activity with a wider impact/benefit to communities of operation and the society as a whole (Compact Voice, 2014). Social value includes the additional environmental and economic benefits achieved and not just the social impacts. Environmental impacts include the reduction of pollution, reducing waste and energy savings while the economic impacts involve apprenticeship opportunities, skills training, use of local suppliers and employment. Temple et al. (2014) argue that there are four steps to unlocking social value as illustrated in Figure1.

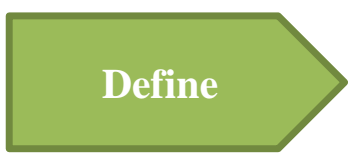

Define the vision

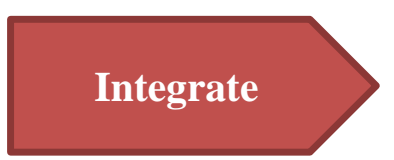

Integrate across the business

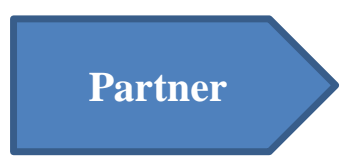

Deliver through partnership

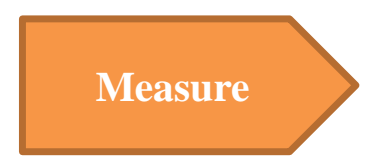

Measure the impact

Figure 1: The social value framework (Temple et al., 2014)

The social value framework is a practical approach to help practitioners define expected social value outcomes and understand how to successfully integrate it across the whole business, partner with relevant stakeholders for delivery and more importantly how to 
measure the difference created as a result of the implementation of the social value policies/strategies.

\subsection{The Social Value Act 2012}

There is call for Housing Associations to robustly pursue the value for money agenda to drive down costs, and this is resulting in the need to adopt new funding models (Chevin, 2013). The Social Value Act 2012 for public services was passed in February 2012 and came into force in January 2013. The Act which is administered by the UK Cabinet Office provides the statutory requirement for all public authorities to consider economic, social and environmental impact of procurement decisions on public service contracts (Cabinet Office, 2012). The Act applies to all contracts above the Official Journal of the European Community (OJEC) procurement thresholds of the 2006 Public Contracts regulations (Compact Voice, 2014) and affects all Local Authorities, Government Departments, NHS Trusts and Agencies (including Clinical Commissioning Groups), Fire and Rescue Services, Housing Associations and Police Services in England (Cunningham, 2012). Even though the Social Value Act is not mandatory for the private sector, there is an increasing interest in the adoption of social value because of the business benefits and the direct impact on profits due to the reputation as a "social friendly" organisation (Tomlins, 2015).

The Social Value Act 2012 has been a game changer requiring public sector organisations to consider how procurement decisions will secure improvements to the economic, social and environmental well-being of society. These considerations should be an integral part of any procurement process and not just an 'add-on'. To create social value when commissioning for services, decisions should not be based on only the price of a service but also what added value/benefit that should be produced by the service (Arvidson and Kara, 2013).

A recent study by the Cabinet Office (2015) identified the main challenges affecting the adoption of the Social Value Act of 2012 in the public sector; awareness of the Act among public sector organisations are mixed with varying understanding on its practical application and lack of a fully developed measurement tool for social value. The adoption of the Social Value Act discourages the lowest price approach to procurement which could not deliver an enhanced value for money throughout the life-cycle of the contract (Arvidson and Kara, 2013). 


\subsection{Delivering Social Value}

As part of the transformation required across the public sector is the delivery of best value to meet the needs of the local communities. Arvidson and Kara (2013) argue that the Social Value Act 2012 has been made more difficult to implement due to the problem of defining what social value means and that public sector procurement commissioners are finding it hard to really focus on social value outcomes, because of the competing goals and priorities.

In order to fully create social value in the public sector, the economic, environmental and social benefits should be considered throughout the procurement process of pre-procurement, selection, contract award, contract conditions and management (Wood and Leighton, 2010). At the pre-procurement stage, considerations should be given to social benefits in tender specifications whiles the award of contract should be based on social considerations to determine the most economically beneficial tender that offer the best value for money. In addition, contractual clauses on social issues such the provision of employment opportunities for the local people could be included in the contract conditions as part of the performance indicators. Defining what social value means and providing evidence that such value can be created should be at the heart of procurement and commissioning (Arvidson and Kara, 2013). From the pre-tender stage, through the evaluation process to the contract management stage, the right processes/systems should be put in place to ensure that social value is achieved at the end of the procurement process. The specification and contract tenders should be designed with added value in mind (Stephens, 2016)

\subsection{Creating social value in the housing sector}

Recent government policy change and spending cuts are impacting on the social housing sector (Chevin, 2013). There is greater pressure on housing providers in England and Wales to create social value outcomes when commissioning public contracts (Tomlins, 2015). Duncan and Thomas (2012) however argue that Housing Associations are in a better position to adopt the Social Value Act. Housing providers are better positioned to drive the realisation of social value through project delivery due to the huge purchasing power and the opportunity to work with contractors and the supply chain. However housing providers are historically known for providing financial support for tenants, learning and skills training and supporting tenants back into work. Social value is widely been used as a tool for accountability, performance improvement and gaining business advantage by housing providers; however quantifying the value created has always been a problem (Tomlins, 2015). 
The Social Value Act 2012 is encouraging housing providers to create and deliver social value outcomes as part of their strategic vision. When housing providers create social value outcomes such as employment, it benefits the state as there is reduced claim on state benefits. Also the cash flow of social housing providers' are improved, because tenants are not likely to get into rent arrears when in employment (Arena Partnership, 2015). In a quantitative survey study by Temple et al. (2014) involving 77 Local Authorities and 123 Housing Associations, 80 percent of respondents rated employment and job-creation as a key local social value priority outcome followed by youth employment, training and volunteering. The study further highlights the enhanced community relationship achieved by Housing Associations and Local Authorities through the delivery of social value outcomes.

The Social Value Act 2012 is changing the procurement practices in the affordable housing sector by prioritising social considerations and well-being over lowest cost in reviewing service contracts (Compact Voice, 2014). Desired local social value outcomes are identified and defined to help in measuring priorities that meet the local objectives. All contractual agreements with service providers should consider economic, social and environmental benefits as part of the service specifications. Social value priorities and outcomes differ from project to project and community to community. Some of the common social value priorities/outcomes delivered in the social housing sector are;

- Equality and diversity

- Apprenticeship and youth activities

- Increased local skills base

- Opportunities for unemployed young people

- Increased physical activity

- Improved physical environment

- Employment skills and training

- Financial resilience

- Community projects

- Digital inclusion

- Improving local environments

- Use of local businesses

- Environmental improvements

- Training and Employability

- Community health and wellbeing 
- Social integration

- Community cohesion

- Volunteering

- Crime and ASB reduction

- Youth activities

- Energy savings

- Fair and ethical trade

- Employment opportunities for disabled people (ALMOs, 2013; Arvidson and Kara, 2013; HM Government, 2014; Temple et al., 2014).

It is a common practice for most housing providers to employ people from the community of operation; the provision of work based health promotions to staff; the promotion of community unity and cohesion aimed at reducing crime; undertaking neighbourhood improvement projects; energy efficiency advice for tenants; apprenticeship opportunities; careers advice in local schools and volunteering opportunities for staff (HM Government, 2014).

\subsection{Measuring Social Value in housing sector}

Social value is now a hot topic in the social housing sector and housing providers are developing methods to best capture the value of the work done; this could be the 'payback' on investment in individual projects or the wider project impacts on the residents, communities and the society. Understanding, capturing and measuring social value in the housing sector is a good decision support mechanism for the investment choices (ALMOs, 2013). Contractors are now required to demonstrate how they can bring enhanced social value to their projects during the procurement process. This may take the form of; hiring construction apprentices, the use of recycled or environmentally friendly raw materials and products, the use of local contractors/suppliers, community consultation to ensure that the project meets local needs and celebrate the project completion through community events.

Quantifying or measuring social value continues to be a big challenge for the implementation of social value in the housing sector, hence the call to develop new techniques for measuring social return on investment (Temple et al., 2014; Chevin, 2013). A number of methods/approaches have however been used in the housing sector to measure social value outcomes; widely known are the Social Return on Investment (SROI) or Social Audit, the use 
of proxy values to give a typical value for certain benefits, Environmental Scanning, Community Impact Analysis, Customer and Stakeholder Involvement, Local Economic Benefits (LM3) and Cost Benefit Analysis (Trotter et al., 2014; Harlock, 2014; Arena Partnership, 2015). In view of the Social Value Act 2012, the affordable housing sector is required to show the wider social, economic and environmental benefits of project delivery by integrating social value outcomes across all departments/sections of the business. Public sector organisations are required to measure the impact of their procurement activities on the wellbeing of individuals, families and local communities, in terms of employment, health, education and economic regeneration when procuring goods, services and works. The provision of new homes for the community enhances the health, confidence, pride and general wellbeing of residents and the wider community.

\section{Research Methodology}

Quantitative research methodology is based on positivism philosophical stance which believes in objective reality and that the phenomena under investigation should be observed and described from an objective perspective (Mackenzie and Knipe, 2006; Creswell, 2009; Opoku et al., 2016). The researcher's philosophical stance helped define the choice of the most appropriate data collection technique; however (Opoku et al., 2016) argue that irrespective of the adopted research methodology, data collection technique used must be suitable for collecting enough data that will help achieve the research objectives. The study therefore adopts the use of quantitative research methodology using questionnaire for data collection; questionnaire offers flexibility in design, relatively cheap and easy to administer (Bryman, 2011). The use of quantitative methodology for the study is due to the exploratory nature of the research and the aim to cover a wider population in the study. The study aimed at capturing and providing an insight into the level of acceptance of the Social Value Act 2012 in the social housing sector in England since it came into force in 2013.

This research therefore adopted electronic method in its questionnaire design, distribution and subsequent data collection processes. A web-based survey was designed using SurveyGizmo software package which is used for creating online surveys, questionnaires and forms and allows the user to capture and analyse any type of quantitative data. A survey link was sent to a total of 100 housing professionals consisting of 50 each from Housing Association and Local Authorities in England. The sample was drawn from social housing providers operating in England alone due to the exploratory nature of this study and the resource constrains. The 
choice of 100 survey participants was deemed enough to provide reasonable data for analysis and good overview of the current state of practice across the United Kingdom. Professionals involved in the study include; Asset Managers, Directors, Business Development Managers and Property Services Managers/Directors charged with the delivery of social housing in England. The survey participants were randomly selected from the 2016 list of registered social housing providers available at the UK Government website. The questionnaire for this study was divided into two main sections for easy analysis and reporting; section one covers general information and section two addresses the key research questions of the study. To increase the response rate of the survey, respondents were contacted by telephone to obtain personal emails before sending the surveys out; follow-up email reminders were sent three weeks after the initial distribution.

\section{Data Analysis and Discussion}

Data from the survey was analysed using the standard Statistical Package for the Social Sciences (SPSS version 24) and Microsoft Excel software. This was used to examine any cross-tabulation, associations or groupings emerging from the survey data through factor and coding analysis. Descriptive statistics involving the use of Percentages, Frequencies and Mean techniques were employed for analysing data related to the characteristics of the respondents and their organisation. Graphical techniques utilised in presenting the results from these analyses included Pie chart, Bar chart and Tables. Inferential statistical techniques were also used to help determine if the sample represents the population, or whether there are differences between two or more groups or if there is a relationship between two or more of the variables (O'Leary, 2005). An analysis of the data shows that a response rate of 58\% was achieved representing 58 responses out of 100 questionnaires sent. This result can be considered as good compared with an average response rate of $48.3 \%$ for a web-based survey (Archer, 2008).

The results of the survey show that, $64 \%$ of respondents are from Housing Associations, with the remaining 36\% coming from Local Authorities in the English social housing sector. This means that less than half of the sample population that participated in the study are from Local Authorities providing social housing in England. The respondents' organisations ranges from small to large in terms of employee size but more than half of the respondents were situated in large size organizations (having over 250 employees); this represents 65\% of 
the total respondents. Medium size organisations (250 or less employees) form 26\%, with 9\% belonging to small size organizations employing up to 50 employees.

There were varied level of job titles when it comes to housing professionals charged with the delivery of social value in the social housing sector. Respondents who describe their current job title as 'Property Services Manager/Director represents 24\% of respondents with $18 \%$ of respondents being "Business Development Managers". However, as much as 36\% of respondents describe their job title as 'other'. These respondents have job titles such as Social Value Business Lead, Information Manager, Sustainability Manager, Energy and Sustainability Co-ordinator, Head of Community Engagement etc.

To establish respondents' level of understanding and knowledge of the Social Value Act 2012, respondents were asked to rate their understanding/knowledge from a scale of "Indepth knowledge" to a level of "No understanding". The result is surprising with $12 \%$ of respondents having in-depth knowledge and another $12 \%$ with no understanding of the Social Value Act 2012 at all. The Social Value Act 2012 has been into force for four (4) years (2013-2017) and the findings reveal that $28 \%$ of respondents are "Reasonably well informed" but as much as $36 \%$ of respondents have just "basic understanding” of the Act. Details and graphical representation of the findings and the breakdown according to the organisational type is illustrated in Figure 2. Out of the $28 \%$ of respondents with "Reasonably well informed” level of knowledge/understanding of the Act, 12\% are from Housing Associations and $16 \%$ from Local Authorities. However when it comes to the breakdown of respondents with just a "basic understanding" of the Social Value Act 2012, 26\% are from the Housing Associations and 10\% from Local Authorities. 


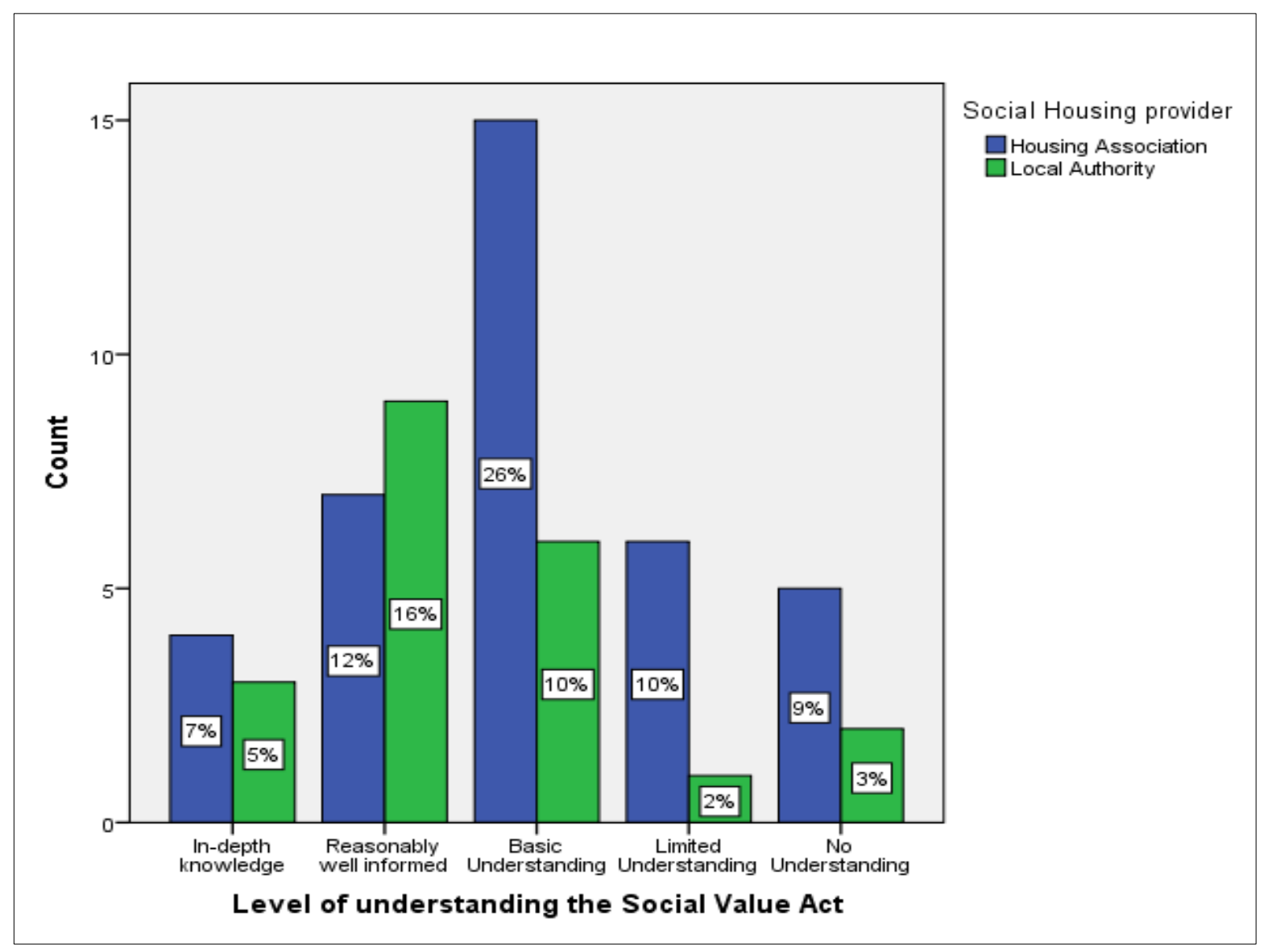

Figure 2 - Level of respondents understanding of the Social Value Act 2012

Respondents were asked how often their organisations consider the Social Value Act 2012 since it came to force in January 2013 and the results is mixed with 33\% of respondents considering the Act "all the time" during procurement. Also 38\% of the respondents consider the Act "some of the time", $19 \%$ occasionally but $10 \%$ of respondents never considered the Social Value Act 2012 in their organisational procurement process at all. It is however important to note that, Housing Associations (HA) consider the Act more often than the Local Authorities (LA); 26\% of HA consider the Act all the time with 7\% from the LA. The detailed breakdown for the two organisations providing social housing in England and how often the Social Value Act 2012 is considered during procurement is shown in Figure 3. 


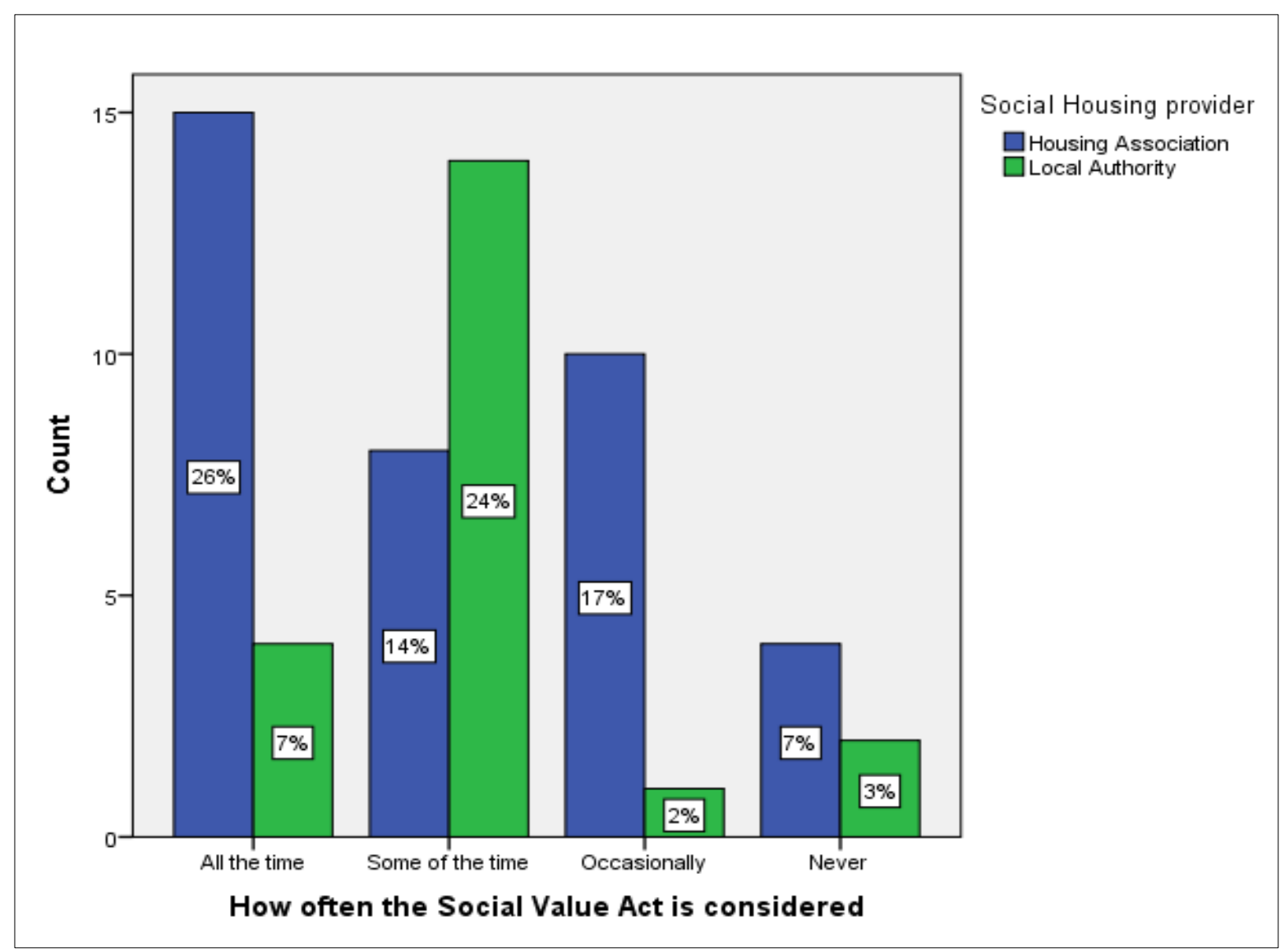

Figure 3 - How often the Social Value Act 2012 is considered

To ascertain if social housing providers and for that matter public sector organisations have developed social value policies/strategies since the Act came into force in January 2013, the result was the same for both organisations with social value policies/strategies and those without at 35\% each. In addition, $18 \%$ are now developing social value policies/strategies four (4) years down the line since the Act came into force. The detail result is illustrated graphically in Figure 4. 


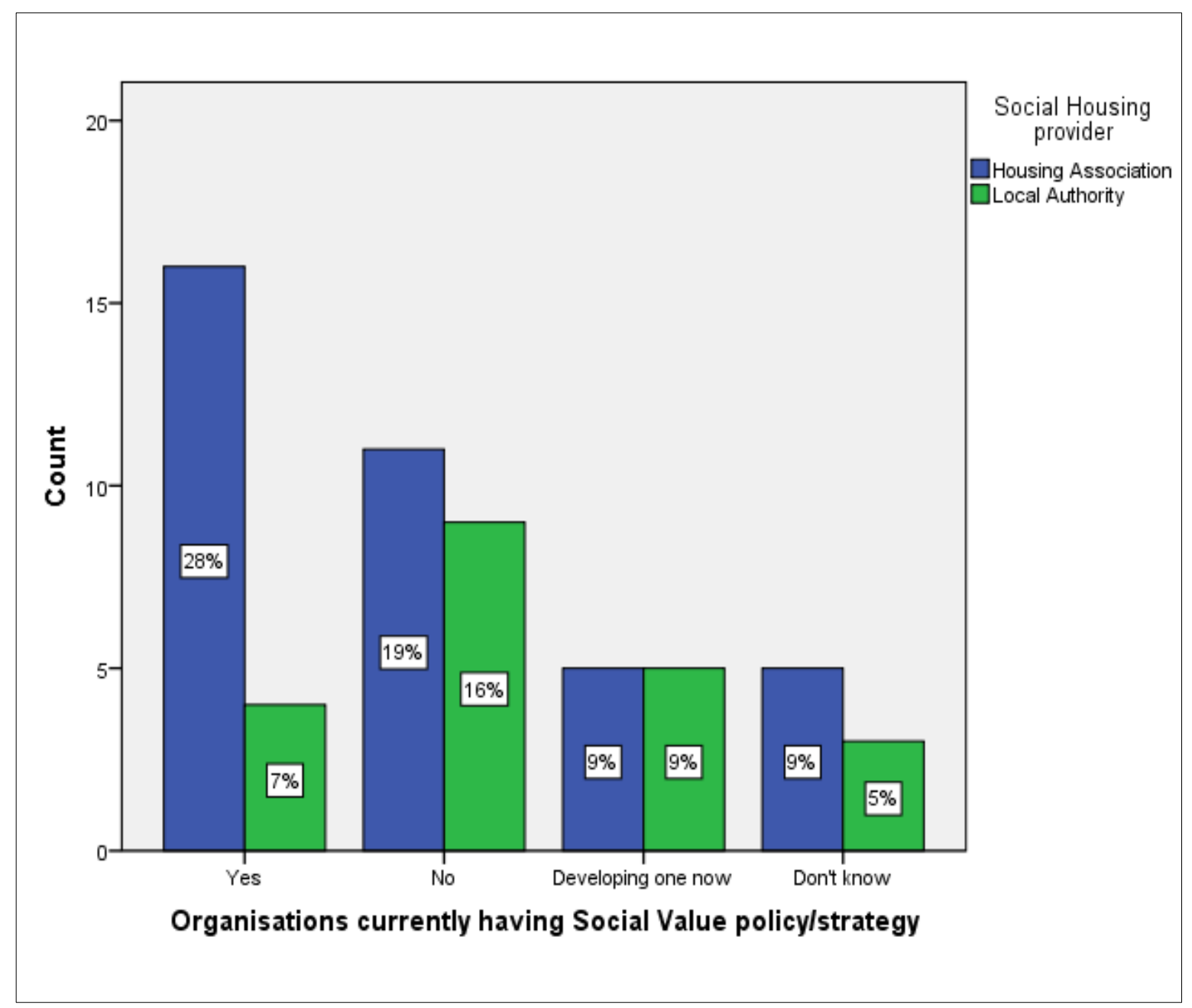

Figure 4 - Social housing providers currently having social value policy/strategy

Again respondents were provided with a list of methods/approaches for measuring social value outcomes established through literature review (Trotter et al., 2014; Harlock, 2014; Arena Partnership, 2015) and the statistical Mean and Standard Deviation of the results is presented in Table 1. In line with findings from the literature, the respondents rated, 'Social return on investment (SROI)', as the most commonly used method for measuring social value outcomes/needs with a mean score of 0.64. The second most commonly used approach/method was the 'community impact analysis' with a mean value of 0.43 , followed by the 'Local economic benefits' with a mean value of 0.26 . However the "use of proxy values" was the least used approach/method for measuring social value needs/outcomes by the respondents with a mean of 0.10 . These results show the level of importance social housing provider organisations put on the local communities of operation. 
Table I - Respondents score of methods of measuring social value outcomes

\begin{tabular}{|c|c|c|c|c|c|c|c|}
\hline \multicolumn{8}{|c|}{ Statistics } \\
\hline & & $\begin{array}{l}\text { Social Return } \\
\text { on } \\
\text { Investment } \\
\text { (SROI) }\end{array}$ & $\begin{array}{l}\text { Social } \\
\text { Audit }\end{array}$ & $\begin{array}{l}\text { The use } \\
\text { of proxy } \\
\text { values }\end{array}$ & $\begin{array}{l}\text { Cost } \\
\text { Benefit } \\
\text { Analysis }\end{array}$ & $\begin{array}{l}\text { Local } \\
\text { economic } \\
\text { benefits } \\
\text { (LM3) }\end{array}$ & $\begin{array}{l}\text { Community } \\
\text { Impact } \\
\text { Analysis }\end{array}$ \\
\hline \multirow[t]{2}{*}{$\mathrm{N}$} & Valid & 58 & 58 & 58 & 58 & 58 & 58 \\
\hline & Missing & 0 & 0 & 0 & 0 & 0 & 0 \\
\hline & Mean & .64 & .12 & .10 & .22 & .26 & .43 \\
\hline \multicolumn{2}{|c|}{ Std. Deviation } & .485 & .329 & .307 & .421 & .442 & .500 \\
\hline
\end{tabular}

To identify social value needs/outcomes that social housing providers have delivered since the introduction of the Social Value Act 2012, respondents were finally asked to rate social value outcomes/needs identified through the literature review (ALMOs, 2013; Arvidson and Kara, 2013; HM Government, 2014; Temple et al., 2014). The statistical Mean and Standard Deviation of the analysis of results is presented in Table 2.

The survey results indicate that, one of the most important social value need/outcome delivered by social housing providers is 'Employment skills and training' with a mean of 0.79, followed by "Crime and anti-social behaviour reduction" as the next most important outcome/need with a mean value of 0.72 . However, it can be seen that, the 'Employment creation', 'Local Apprenticeship' and 'Community improvement projects' rated third, fourth and fifth most important social value outcomes/needs respectively with a mean value of 0.69 , 0.50 and 0.47 respectively. The choice of social value outcome is mainly based on the needs of the local communities in which these organisations operate. It is therefore apparent from the findings that, employment and crime related issues are very important to both social housing providers and the local communities. 
Table II - Respondents score of delivered social value outcomes/needs

\begin{tabular}{|l|l|l|l|l|}
\hline Social Value Needs/Outcomes & N & Sum & Mean & $\begin{array}{l}\text { Std. } \\
\text { Deviation }\end{array}$ \\
\hline Employment creation & 58 & 40 & .69 & .467 \\
\hline Equality and diversity & 58 & 21 & .36 & .485 \\
\hline Local apprenticeship & 58 & 29 & .50 & .504 \\
\hline Employment skills and training & 58 & 46 & .79 & .409 \\
\hline Community improvement projects & 58 & 27 & .47 & .503 \\
\hline Improved local environments & 58 & 12 & .21 & .409 \\
\hline Use of local businesses & 58 & 13 & .22 & .421 \\
\hline Health and wellbeing & 58 & 5 & .09 & .283 \\
\hline Volunteering & 58 & 9 & .16 & .365 \\
\hline Crime and anti-social behaviour reduction & 58 & 42 & .72 & .451 \\
\hline Valid N & 58 & & & \\
\hline
\end{tabular}

The Kruskal-Wallis ANOVA test was used to explore significant differences between the two social housing provider organisations (Housing Associations and Local Authorities) and their response to the survey by comparing the Mean scores. The top five most important delivered social value outcomes/needs identified in the descriptive analysis were 'Employment skills and training', 'Crime and anti-social behaviour reduction', 'Employment creation', 'Local Apprenticeship' and 'Community improvement projects'. The results of the Kruskal-Wallis one way ANOVA test for a K-Independent sample showing the five most important delivered social value outcomes/needs are presented in Table 3. The key information from the output of the analysis were; the Chi-Square value, the degrees of freedom (df) and the significance level (Asymp. Sig).

The result from the above shows that there was no statistically significant difference between the type of social housing provider and the delivered social value outcomes/needs with Kruskal-Wallis test of $(\mathrm{H}(1)=0.535, P=0.465)$ for 'Crime and anti-social behaviour reduction'; $(\mathrm{H}(1)=3.065, P=0.080)$ for 'Community improvement projects'; $(\mathrm{H}(1)=$ 0.053, $P=0.818$ ) for 'Employment skills and training' ; $(\mathrm{H}(1)=0.073, P=0.787)$ for 'Local apprenticeship' and $(\mathrm{H}(1)=0.092, P=0.762)$ for 'Employment creation'. At the significant level of ( $\alpha=0.01)$, there exists a very strong evidence to conclude that there is no difference between the two organizational types (Housing Associations and Local Authorities) classified 
in the survey based on the test scores. There was therefore no statistical difference in delivered social value outcomes/needs across the social housing providers identified in the UK housing sector. As a result it can be asserted that, social housing provider are driven by the same factors when it comes to priority social value outcomes/needs to be delivered irrespective of the type of organisation .

Table III - Kruskal-Wallis ANOVA test of priority social value outcomes on type of social housing provider

\begin{tabular}{|c|c|c|c|c|c|}
\hline \multicolumn{6}{|c|}{ Test Statistics $^{a, b}$} \\
\hline & $\begin{array}{l}\text { Crime and } \\
\text { anti-social } \\
\text { behaviour } \\
\text { reduction }\end{array}$ & $\begin{array}{l}\text { Community } \\
\text { improvement } \\
\text { projects }\end{array}$ & $\begin{array}{l}\text { Employment } \\
\text { skills and } \\
\text { training }\end{array}$ & $\begin{array}{l}\text { Local } \\
\text { apprenticeship }\end{array}$ & $\begin{array}{l}\text { Employment } \\
\text { creation }\end{array}$ \\
\hline $\begin{array}{l}\text { Chi- } \\
\text { Square }\end{array}$ & .535 & 3.065 & .053 & .073 & .092 \\
\hline df & 1 & 1 & 1 & 1 & 1 \\
\hline $\begin{array}{l}\text { Asymp. } \\
\text { Sig. }\end{array}$ & .465 & .080 & .818 & .787 & .762 \\
\hline \multicolumn{6}{|c|}{ a. Kruskal Wallis Test } \\
\hline
\end{tabular}

In addition, a correlation was performed to determine the relationship between the top five (5) most important delivered social value outcomes/needs from the Mean scores and the result was varied. The result which is presented in Table 4 show a significant correlation between 'employment creation' and 'Crime and anti-social behaviour reduction' ( $r s=.336$, $p=.010$, two-tailed); 'employment creation' and 'employment skills and training' ( $r s=.485$, $p=.000$, two-tailed) and 'employment skills and training' and 'Crime and anti-social behaviour reduction' ( $r s=.447, p=.000$, two-tailed). However, there was no significant correlation between confidences in the rest of the top five (5) most important delivered social outcomes/needs. 
Table IV - Correlation of top five most important social value outcomes/needs

\begin{tabular}{|c|c|c|c|c|c|c|c|}
\hline \multicolumn{8}{|c|}{ Correlations } \\
\hline & & & 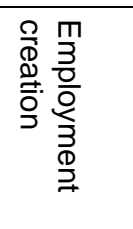 & 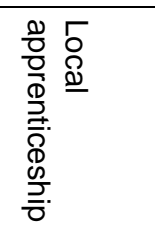 & 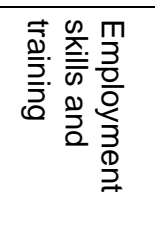 & 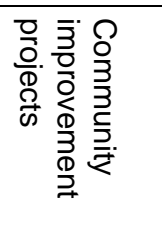 & 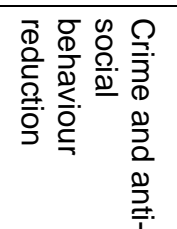 \\
\hline \multirow{15}{*}{$\begin{array}{l}\text { Spearman' } \\
\text { s rho }\end{array}$} & \multirow{3}{*}{$\begin{array}{l}\text { Employment } \\
\text { creation }\end{array}$} & $\begin{array}{l}\text { Correlation } \\
\text { Coefficient }\end{array}$ & 1.000 & . 149 & $.485^{\star *}$ & .252 & $.336^{* \star}$ \\
\hline & & $\begin{array}{l}\text { Sig. (2- } \\
\text { tailed) }\end{array}$ & & 264 & .000 & .056 & .010 \\
\hline & & $\mathrm{N}$ & 58 & 58 & 58 & 58 & 58 \\
\hline & \multirow{3}{*}{$\begin{array}{l}\text { Local } \\
\text { apprenticeshi } \\
\text { p }\end{array}$} & $\begin{array}{l}\text { Correlation } \\
\text { Coefficient }\end{array}$ & 149 & 1.000 & .085 & .035 & -.154 \\
\hline & & $\begin{array}{l}\text { Sig. (2- } \\
\text { tailed) }\end{array}$ & .264 & . & .525 & .797 & .247 \\
\hline & & $\mathrm{N}$ & 58 & 58 & 58 & 58 & 58 \\
\hline & \multirow{3}{*}{$\begin{array}{l}\text { Employment } \\
\text { skills and } \\
\text { training }\end{array}$} & $\begin{array}{l}\text { Correlation } \\
\text { Coefficient }\end{array}$ & $.485^{* *}$ & .085 & 1.000 & .221 & $.447^{\star *}$ \\
\hline & & $\begin{array}{l}\text { Sig. (2- } \\
\text { tailed) }\end{array}$ & .000 & .525 & & .096 & .000 \\
\hline & & $\mathrm{N}$ & 58 & 58 & 58 & 58 & 58 \\
\hline & \multirow{3}{*}{$\begin{array}{l}\text { Community } \\
\text { improvement } \\
\text { projects }\end{array}$} & $\begin{array}{l}\text { Correlation } \\
\text { Coefficient }\end{array}$ & .252 & .035 & .221 & 1.000 & .035 \\
\hline & & $\begin{array}{l}\text { Sig. (2- } \\
\text { tailed) }\end{array}$ & .056 & .797 & .096 & . & .796 \\
\hline & & $\mathrm{N}$ & 58 & 58 & 58 & 58 & 58 \\
\hline & \multirow{3}{*}{$\begin{array}{l}\text { Crime and } \\
\text { anti-social } \\
\text { behaviour } \\
\text { reduction }\end{array}$} & $\begin{array}{l}\text { Correlation } \\
\text { Coefficient }\end{array}$ & $.336^{* *}$ & -.154 & $.447^{* *}$ & .035 & 1.000 \\
\hline & & $\begin{array}{l}\text { Sig. (2- } \\
\text { tailed) }\end{array}$ & .010 & .247 & .000 & .796 & \\
\hline & & $\mathrm{N}$ & 58 & 58 & 58 & 58 & 58 \\
\hline
\end{tabular}

The study shows that despite the introduction of the Social Value Act 2012, compliance level in the housing sector is still very low. The level of understanding the Social Value Act 2012 among professionals in the housing sector is not encouraging at all; $12 \%$ of respondents have no understanding of the Act which is supposed to enhance value for money in the public sector.

Social housing sector organisations are not considering the delivery of social value outcomes/needs in their organisations' procurement process; as much as $10 \%$ of respondents' organisations never consider social value outcomes/needs in the delivery of social housing projects. Housing Associations and Local Authorities should be encouraged to integrate social value through contracts in the procurement of goods and services.

It is surprising to know that, as much as $35 \%$ of respondents' organisations do not have social value policies/strategies to guide such organisations in the implementation of the Social Value Act 2012. However, it is not surprise from the survey result that Social Return on 
Investment (SROI) is the most commonly used method/approach for measuring social value outcomes/needs in the social housing sector. The Social Return on Investment (SROI) methodology is well known in the public sector for measuring and accounting for value for money by using monetary values to represent social, environmental and economic outcomes and benefits of the organisations' activities. The study shows that employment skills and training, crime and anti-social behaviour reduction, employment creation, local apprenticeship and community improvement projects are social value priority outcomes/needs mostly delivered in the social housing sector in England.

\section{Conclusions}

In an era where the public sector is required to deliver more with less, social housing providers are required to provide value for money during all procurement processes in order to receive further funding support from the UK Government. At the heart of achieving value for money is the expectation that social housing providers create social value outcomes in the delivery of social housing. The Social Value Act 2012 which came into force in January 2013 is applicable to all public sector organisations and are required to consider economic, social and environmental impact in all procurement decisions for the well-being of society. Defining and measuring social value is difficult; however social value has been described as the additional value created in the delivery of the primary service that has a wider impact on society, especially in the communities of operation. As part of the efforts by public sector organisations to measure the social, economic and environmental impact of their procurement activities on the wellbeing of society, Social Return on Investment (SROI) is the most commonly used approach/method when measuring social value outcomes/needs.

The study shows that, the level of understanding of the Social Value Act 2012 in the social housing sector in England is low with only 12\% of professionals charged with the responsibility to embed social value outcomes having in-depth understanding of the Act. Additionally, another $12 \%$ of the respondents have no understanding of the Social Value Act 2012 at all. Once again the results show that some social housing sector organisations never consider social value outcomes/needs in the delivery of social housing projects, however about one-third (35\%) of the respondents consider social value outcomes all the time during the procurement process. Many of the respondents' organisations in the social housing sector in England do not have social value strategy or policy to help with the implementation of the social value outcomes/needs. In practice, employment skills and training, and crime and anti- 
social behaviour reduction are the top two most social value priority outcomes/needs identified in the social housing sector. This is a clear evidence of how the Social Value Act 2012 could help tackle some of the societal problems in the UK if the Act is enforced. Public sector organisations can provide opportunities for the citizens in the community of operation by adopting the Social Value Act 2012 in the procurement process.

The study could help social housing providers in attempt to implement programmes that can contribute to the creation of social value outcomes. To improve the implementation of the Social Value Act 2012 in the social housing sector, organisations should evaluate contract proposals on the basis of social value creation and not just on the lowest tender price. The social housing sector has the purchasing power to make a significant contribution in delivering social value outcomes if the right leadership direction is provided to embed social value outcomes in the planning, budgeting and reporting processes of all social housing projects and programmes. It is recommended that a further study involving qualitative data collection should be conducted to help capture social housing professionals' opinions and reasons underpinning the results of this study.

\section{References}

ALMOs (2013), Social value: long-term benefits of ALMOs work, NFA Best practice guide, Issue 6 - February 2013, Coventry: National Federation of Arm's Length Management Organisations (ALMOs)

Archer, T.M. (2008), Response rates to expect from web-based surveys and what to do about it, Journal of Extension, Vol. 46 No. 3, available at: http://www.joe.org/joe/2008june/rb3.php (accessed $10^{\text {th }}$ November 2016).

Arena Partnership (2015), 5 Minute Guide to Social Value: What it means for the UK Social Housing Sector, www.arenapartnership.co.uk, Arena Partnership, Norfolk, UK

Arvidson, M. and Kara, H. (2013), Putting evaluations to use: from measuring to endorsing social value, Working Paper 110, Birmingham: Third Sector Research Centre

Bryman, A. (2012), Social Research Methods, $4^{\text {th }}$ edition, Oxford: Oxford University Press

Cabinet Office (2015), Social Value Act review report, Available at: https://www.gov.uk/government/.../Social_Value_Act review_report_150212.pdf, London: The Cabinet Office, (Accessed on 15 November 2016).

Cabinet Office (2012), The Public Services (Social Value) Act 2012-advice for commissioners and procurers: Cabinet Office Procurement Policy Note Information Note 
10/12 20th December 2012, Available at: https://update.cabinetoffice.gov.uk/resourcelibrary/public-procurementnote, (Accessed on 15 November 2016).

Chevin, D. (2013), Social hearted, commercially minded a report on tomorrow's housing associations, London: The Smith Institute

Compact Voice (2014), Understanding Social Value: A guide for local Compacts and the voluntary sector, available at:

http://www.compActvoice.org.uk/sites/default/files/social_value_guidance_2014.pdf, (Accessed on $3^{\text {rd }}$ December 2015)

Creswell, J.W. (2009), Research Design: Qualitative, Quantitative, and Mixed Methods Approach, $4^{\text {th }}$ edition, London: SAGE Publications Ltd.

Cunningham, S. (2012), Public services (Social Value) Act 2012, Briefing Paper, London: National Housing Federation

DEFRA (2006), Procuring the Future, Sustainable Procurement National Action Plan: Recommendations from the Sustainable Procurement Task Force, London: Department for Environment, Food and Rural Affairs (DEFRA)

Duncan, P. and Thomas, S. (2012), Acting on Localism: The role of housing associations in driving a community agenda, Lincoln, ResPublica

Harlock, J. (2014), From outcomes-based commissioning to social value? Implications for performance managing the third sector, International Journal of Management Reviews, 16 (4), 417-36

HM Government (2014), The Public Services (Social Value) Act 2012: One Year On, London: Cabinet Office, Available at:

http://buysocialdirectory.org.uk/sites/default/files/public_services_social_value_Act__one_year_on.pdf, (Accessed on 10 October 2016).

Johnson, B and Sommariva, A. (2012), More than just homes: Measuring Moat's true social value contribution, Moat thought leader essay, Available at: www.moat.co.uk, Dartford, UK

Jones, M. and Wilson, K. (2014), Delivering value for money in asset management, available at:http://www.cih.org/resources/PDF/Marketing\%20PDFs/Presentations/Karen\%20and\%20M ervyn\%20Asset\%20Tuesday\%204pm.pdf, (Accessed on 16 September 2016).

Mackenzie, N. and Knipe, S. (2006), Research dilemmas: Paradigms, methods and methodology. Issues in Educational Research, 16(2) 193-205.

NHS (2015), Creating Social Value, Public Health England, The Sustainable Development Unit, www.sduhealth.org.uk/focus, National Health Service, Cambridge, UK.

O'Leary, Z. (2005), Researching Real-World Problems: A guide to methods of inquiry. London: Sage 
Opoku, A., Ahmed, V. and Akotia, J. (2016), Choosing appropriate Research Methods, in: V. Ahmed, A. Opoku, and Z. Aziz, (Eds.), Research Methodology in the Built Environment: A Selection of Case Studies, (London, Routledge), pp. 32-49

Stephens, G. (2016), Orbit Group \& Service Matters Social Value: The Challenge of Embedding Social Value in Procurement, The Chartered Institute of Procurement \& Supply (CIPS), Stamford-Lincolnshire, UK

Temple, N., Wigglesworth, C. and Smith, C. (2014), Communities Count: The Four Steps of Unlocking Social Value, Social Enterprise UK, London, UK

Tomlins, R. (2015), Social Value Today: Current public and private thinking on Social Value, www.housemark.co.uk, HouseMark, Coventry, UK

Trotter, L., Vine, J., Leach, M. and Fujiwara, D. (2014), Measuring the Social Impact of Community Investment: A Guide to using the Wellbeing Valuation Approach, London: Housing Association Charitable Trust (HACT)

Wood, C. and Leighton, D. (2010), Measuring Social Value: The Gap Between Policy and Practice, London: Demos UK, 2010 